\section{Klaus Berntsen og Carl Nielsen}

af forskningsassistent Kirsten Flensborg Petersen

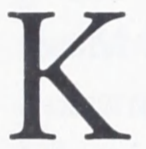

omponisten Carl Nielsen skriver i et brev fra 1905 til politikeren Klaus Berntsen:

„Det lader til at det netop skal være ved vendepunkterne i mit Liv at De er der med en trofast og hjælpende Haand og derfor [er] jeg Dem saa meget mere Tak skyldig."

Brevet er skrevet umiddelbart efter, at avisen "Søndagsbladet" havde bragt en artikel af Klaus Berntsen om Carl Nielsen.

Klaus Berntsen blev født i Eskildstrup på Fyn. I høj- og friskolekredse på landet blev han uddannet til lærer af bl.a. Kristen Cold og Kristian Appel. Fra 1862 til 1882 var han forstander ved Friskolen i Højby og fra 1881 til 1889 ved højskolen i Særslev.

Klaus Berntsen var en initiativrig mand i det lokale miljø: som redaktør og udgiver: først af et ugeblad for friskolens folk, Fylla, som senere kom til at hedde Friskolen Tidende, dernæst af Fyns Amtsavis (fra 1872) og endelig af Assens Amtsavis (fra 1887), som aktiv deltager i skyttesagen: han ledede Skytteforeningen i Odense fra 1866, Skytteforeningen i Højby fra slutningen af 1860erne, og på landsplan var han formand for De Danske Skytteforeninger fra 1910 til 1922, som politiker: i Højby sogneråd i 6 år, i Særslev sogneråd i 18 år fra omkring 1882, som bestyrelsesmedlem i en lang række foreninger.

\section{1873 blev Klaus Berntsen} valgt til Folketinget for „De forenede Venstre“. Fra 1908 var han 1. viceformand for Folketinget, og i flere perioder var han minister: indenrigsminister fra okt. 1908 til okt. 1909, konseilspræsident og forsvarsminister fra juli 1910 til juni 1913 , forsvarsminister fra maj 1920 til okt. 1922, minister uden portefeuille fra okt. 1922 til april 1924 .

Af større politiske sager deltog han i forberedelsesarbejdet til revision af Grundloven i 1915. Ligeledes arbejdede han i kommissionen omkring Det Kongelige Teater i 1893, og i denne sammenhæng må også nævnes genindførelsen af musikken ved de militære regimenter i 1911.

Klaus Berntsen fremstår som en mand af mange ord og høje idealer. Som fri- og højskolemand var han en yndet foredragsholder, talrige annoncer $\mathrm{i}$ Fyns Stifttidende vidner herom, og af efterladte papirer, taler m.v. på Rigsarkivet fremgår, at han var en stor fortaler for Grundtvigs tanker. I samtiden (1913) beskrives han af E. Henrichsen således: „Den Aand, der har bygget Værket, er jo Grundtvigs, men blandt dets praktiske Kræfter er Klaus Berntsen en af de første".

Klaus Berntsen kendte Carl Nielsens far, Niels Jørgensen, fra egnen omkring Højby. Denne var en meget efterspurgt spillemand, men han spillede overvejende andres melodier. Fra hans hånd kendes kun en enkelt komposition, Højby Skyttemarch, som er kom- 


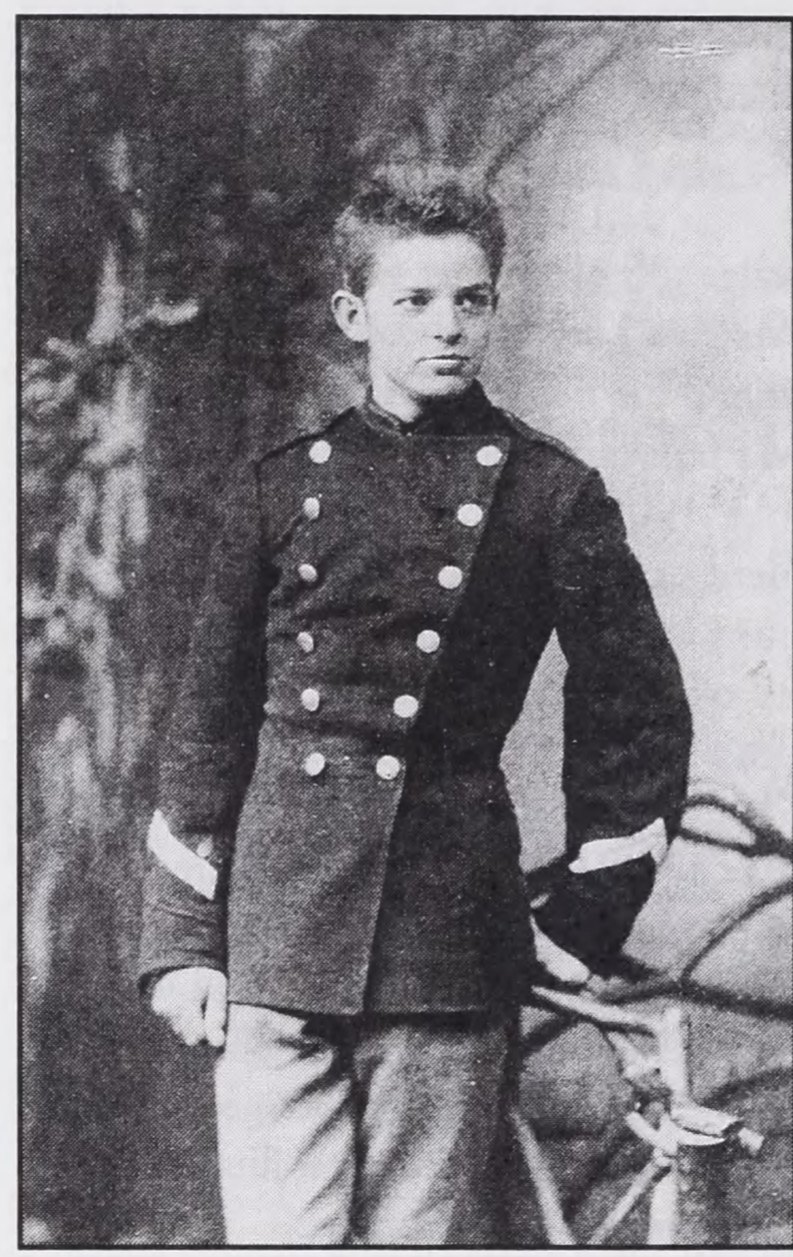

Carl Nielsen, 1882.

poneret til Højby Skytteforening, mens Klaus Berntsen var leder. PD det originale nodeblad har Klaus Berntsen skrevet:

„Komponeret af Karl Nielsens Fader og er nu af Sønnen udsat for flere Instrumenter og indført i Hæren efter at jeg var bleven Krigsminister".

Han hentyder her til, at marchen senere blev arrangeret for militærorkesterbesætning af Carl Nielsen og spillet for Klaus Berntsen på Bådsmandsstrædes Kaserne.

Den nære relation familierne imellem fortsættes, idet Klaus Berntsens søn, Aage Berntsen, har skrevet flere tekster til Carl Nielsen, bl.a. Fynsk Forår, komponeret i 1921.
At Klaus Berntsen og Carl Nielsen blev meget gode venner, findes mange eksempler på. I komponistens dagbøger og breve er der henvisninger til middage eller i selskab med Klaus Berntsen, f.eks. d. 26.1.1909 „Hos Kl: Berntsen hyggeligt om Aftenen“ og d. 5.7.1910 „Kl: Berntsens Ministerium udnævnt. Sendte ham Blomster". Mere direkte udtrykker Carl Nielsen sin taknemmelighed eller rettere beundring for Klaus Berntsen i et brev til ham d. 3 . marts 1905:

„Hvad jeg personlig skylder Dem ved at have set og hørt Dem som Barn og ved at have set den vidunderlig[e] Virkning en enkelt Mand kan have paa en hel Egn har jeg ikke omtalt i det Biografiske men jeg har Lyst til at sige Dem det nu; thi De aner neppe selv hvor langt ud og dybt ned De trængte i Folk[s] Sind dengang. De stod for os allesammen som en Eventyr og som noget helt nyt, varmt og friskt. Der var Haab naar vi saa Dem og vi blev helt glade naar vi hørte Dem og fik en Følelse af at vi ogsaa selv var Mennesker af bedre Slags; og vi blev virkelig bedre."

De varme følelser var gensidige. Da Klaus Berntsen var forhindret $\mathrm{i}$ at deltage i Carl Nielsens 60 års fødselsdag, skriver han i stedet et brev d. 8 . juni 1925:

„... Det er jo ingen Alder, men dog lang nok til, at jeg standser et Øjeblik og ser tilbage paa den Tid, De var Dreng og fulgte med Deres Fader til Højby og spillede ved vore Sammenkomster og Baller i Højby Skytteforening, hvor mindes jeg Deres Fader, som jeg holdt saa meget af, og fra hvem De 
har arvet den Gnist, som han ikke fik udviklet, men som det er en stor Lykke og Velsignelse ikke blot for Dem selv men for hele vort Folk ja for mangfoldige uden for Landets Grænser, at De i saa rigt Maal har plejet og ladet Dem inspirere af. Hvor Tiden dog gaar hurtigere, end vi selv aner, men hvor er det end [en] Lykke for Dem og en stor Glæde for andre og ikke mindst for mig, Deres og Deres Faders gamle Ven, at se, hvor godt De har benyttet Tiden, saa De nu staar skattet af alle og beundret som en af Danmarks gode Sønner, hvis Navn aldrig vil død [dø], men bevares i Folkets taknemmelige Erindring, og hertil bidrager ikke mindst de herlige Melodier, som De har komponeret til mange af vore gode Sange. Jeg glæder mig ofte ved at komme til Møder omkring i Landet og høre gamle og unge Mennesker med Liv og Glæde synge Deres Melodier, der er saa danske i Bund og Grund ..."

Klaus Berntsen nævner i sine erindringer sit første møde med Carl Nielsen. Fra ganske ung havde Carl Nielsen spillet violin til diverse bondegilder med sin fars spillemænd, og Klaus Berntsen beskriver første gang, han hørte ham spille, saaledes:

„Engang kom de ogsaa over og spillede i Højby Skytteforening, som jeg ledede. Vi lagde mærke til, hvor flinkt den unge mand håndterede Violinen, og nogle Gårdmænd og jeg blev enige om at hjælpe ham frem i Verden."

Det lader til, at det på mange måder lykkedes Klaus Berntsen at bidrage til Carl Nielsens fremgang. På hans foranledning fik Carl Nielsen, da han i 1879 kom til Regimentsmusikken i Odense, ud over den militære skoling undervisning i violin hos Kantoren ved Sct. Knuds Kirke, Carl Larsen, der var uddannet i København, og var dirigent for Odense Musikforening.

Klaus Berntsens assistance begrænser sig ikke til de tidlige år. De følgende eksempler viser, hvordan han gentagne gange arbejder for promovering af Carl Nielsen.

\section{Optagelsen på konservatoriet \\ Tforbindelse med Carl Nielsens op- \\ tagelse på Kjøbenhavns Musikkon- servatorium i 1884 spiller Klaus}

Berntsen en stor rolle. Carl Nielsen skriver i sine selvbiografiske notater, at han på eget initiativ var taget til København i maj 1883 for at spille violin for professor Niels W. Gade på Konservatoriet. Denne henviste med hensyn til violinspillet til Valdemar Tofte, men så dog på en komposition, en strygekvartet, som Carl Nielsen havde komponeret. Om Klaus Berntsens betydning skriver Carl Nielsen:

„Jeg er imidlertid sikker paa at Gade havde glemt dette Møde og jeg neppe var bleven antaget alene paa Violinpræstationen hvis ikke $\mathrm{Kl}$ : Berntsen havde talt med ham i Mellemtiden inden Optagelsen. Senere spurgte Gade mig om det var mig Berntsen havde talt om".

I Min fynske barndom fra 1927 beskriver Carl Nielsen forløbet lidt anderledes. Her kan læses, at Klaus Berntsen var vidende om hans rejse til København, og at han tillige havde skrevet et brev til Niels W. Gade, som Carl Nielsen medbragte. 


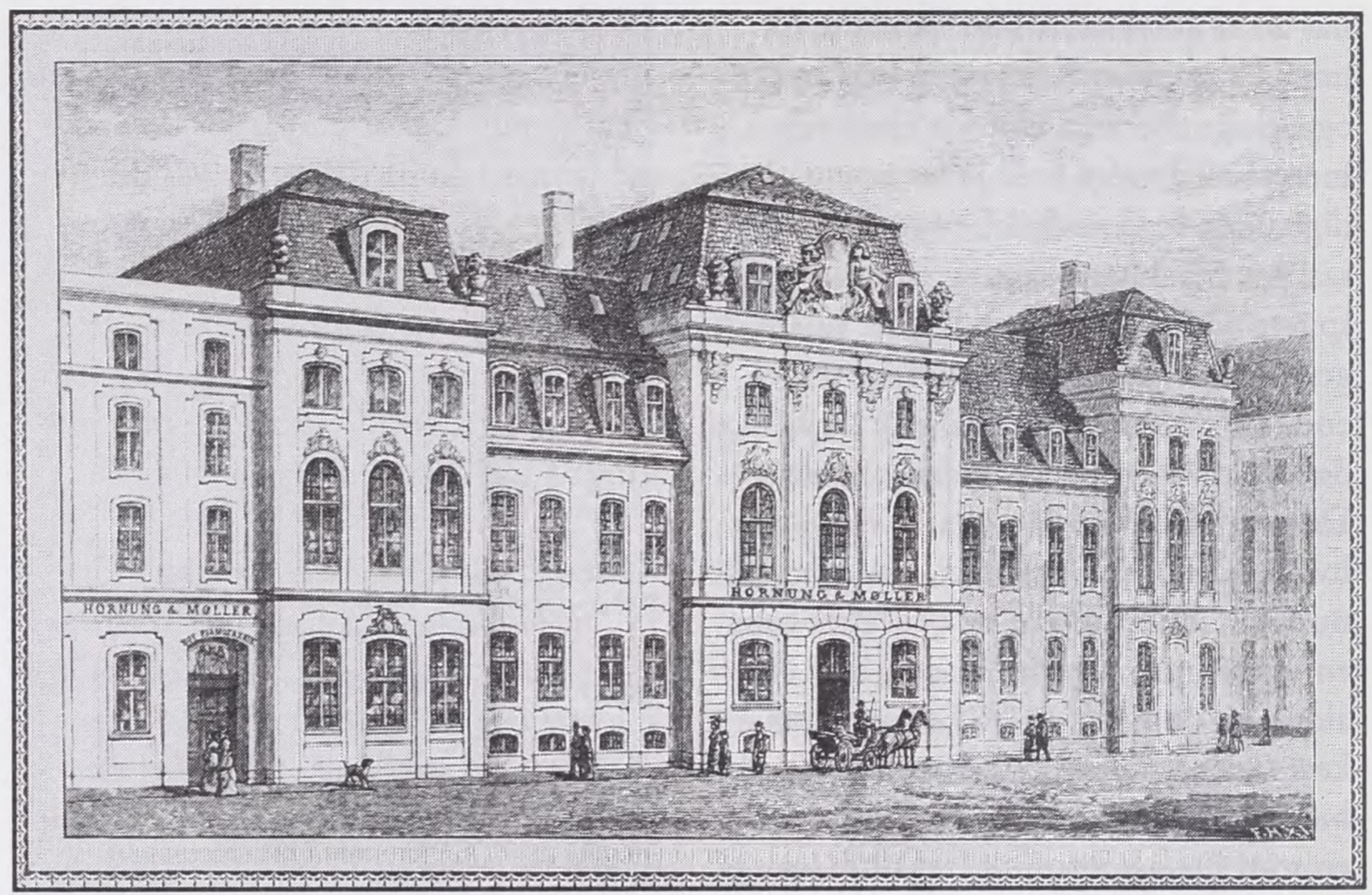

Kjobenhavns Musikkonservatorium lå i Dehns pala i Bedgade. Her på reklametryk fra 1860.

Klaus Berntsen er dog mindre beskeden angående sin indsats. Han nævner i sine erindringer, at en henvendelse fra Klokker Larsen i Odense fik ham til at arbejde for Carl Nielsens optagelse på konservatoriet. Han opsøgte Niels W. Gade for at arrangere et møde mellem ham og Carl Nielsen. Gade var først noget vrangvillig, men det lykkedes Klaus Berntsen at få overtalt ham, og efter mødet skulle Gade ifølge Klaus Berntsen være blevet så begejstret, at han tildelte Carl Nielsen en friplads på konservatoriet.

Helt så enkelt gik det nu ikke. Carl Nielsen var indstillet til den ordinære optagelsesprøve på konservatoriet i december 1883, hvor han spillede for Niels W. Gade, Valdemar Tofte og J.P.E. Hartmann. Han blev optaget og stude- rede ved konservatoriet fra 1884 til 1886.

At Klaus Berntsen brugte sin indflydelse og sine overtalelsesevner for at bidrage til optagelsen på Konservatoriet, hersker der ingen tvivl om. Det interessante er hans motivering for det. I et interview i 1902 siger han: „...et lille Land som Vort har ikke Raad til at vise Muligheder tilbage“.

\section{Finansloven}

T nov. til dec. 1902 er Klaus Berntsen involveret $\mathrm{i}$ en avispolemik om Carl Nielsen. I forbindelse med uropførel sen af operaen Saul og David i 1902 findes på forsiden af avisen „Vort Land“ d. 30. november et interview med Klaus Berntsen, hvor han fortæller om sine tidligste erindringer om Carl Nielsen og 
hans far. Heri nævner han sin indflydelse på, at Carl Nielsen få år tidligere blev indstillet til økonomisk støtte via Finansloven. Denne kommentar får modstand. D. 3. december kan man i samme avis læse et indlæg fra folketingsmand Jens Busk, som hævder, at Klaus Berntsen ikke havde del i den sag. Han nævner i stedet et andet medlem af Folketinget, Andreas Kristensen Rosager. Klaus Berntsen benægter d. 5. december i „Vort Land“, at han skulle have erklæret sig som den person, der alene bevirkede, at Carl Nielsen fik understøttelsen. Han påstår, at han er fejlciteret.

Fra april 1901 fik Carl Nielsen udbetalt en statslig understøttelse på 800 kr. om året. Ydelsen var i første om-gang tidsbegrænset til 3 år, men herefter modtog Carl Nielsen er fast årlig ydelse. Hvorvidt Klaus Berntsen eller A.K.

Rosager var initiativtager, er vanskeligt at konstatere. Både Jens Busk og A.K.

Rosager sad i det finansudvalg, som d. 2. oktober 1900 fremsatte lovforslag til Finansloven 1901-1902. Her var Klaus Berntsen ikke til stede. Heller ikke ved genforhandlingen 3 år senere sad Klaus Berntsen i Finansudvalget.

Rosager og Jens Busk tilhørte det samme parti: Venstre-reformpartiet, som blev dannet i 1895 gennem splittelse af partiet Rigsdagens Venstre. Venstre-reformpartiet videreføres i 1905 som Det Radikale Venstre. Klaus Berntsen tilhørte en anden gren af Venstre: Det Forhandlende Venstre, så det er nærliggende at antage, at der også er partipolitiske markeringer i denne sag.

\section{Promovering}

T 1905 omtaler Klaus Berntsen igen

Carl Nielsen i en artikel til Sondagsbladet Ugeblad for Land og By d. 11. juni. Artiklens indhold er en næsten ordret gengivelse af de biografiske oplysninger, Carl Nielsen sender Berntsen i brev da-teret 3.3.1905 samt supplerende oplysninger i brev dateret 24.5.1905. Artiklen må ses som et forsøg på gennem øget omtale af Carl Nielsen at skaffe ham nye engagementer. Carl Nielsen var efter eget ønske fratrådt som violinist i Det Kongelige Kapel d. 30. juni 1905 og stod derfor uden andre faste indtægter end den årlige ydelse på Finansloven.

\section{Kapelmesterstillingen}

$\mathrm{E}$ $\mathrm{n}$ anden sag, Klaus Berntsen engagerede sig i, var Carl Nielsens udnævnelse til Kapelmester ved Det Kongelige Teater i 1908. Han skriver til Carl Nielsen således i et brev dateret 9.3.08:

„Det var med nogen Overraskelse, jeg saa den ny Kapelmester blev udnævnt, uden at man samtidigt var Klar over, hvem der skulde være anden Kapelmester, og Arbejdets Deling mellem de to. Jeg bebrejdede Ministeren, at han ikke samtidigt havde knyttet Dem til Theatret.

Nu kom Ministeren i Aften til mig og fortalte, at han havde havt en Samtale med Theaterschefen om Dem, og at han ansaa det som givet, at De tog mod Stillingen som 2den Kapelmester.

Jeg tilråder Dem indstændigt at komme til Forstaaelse med Theaterchefen og Rung om at overtage Stillin- 
gen som 2 den Kapelmester, thi er De blot knyttet fast til Theatret, saa skal De se, at Forholdene nok vil udvikle sig tilfredsstillende for Dem."

$\mathrm{B}$

aggrunden var, at 1. Kapelmester ved Det Kongelige Teater, Johan Svendsen, i 1908 havde fået sin afsked. Teatrets 2. Kapelmester gennem flere år, Frederik Rung, var kandidat til posten som 1. Kapelmester, og som ny 2. Kapelmester foreslog Johan Svendsen Carl Nielsen. Dette forslag blev støttet af Klaus Berntsen. Allerede i 1905 nævnte Klaus Berntsen i sin artikel til Sondagsbladet, at en kapelmesterpost til Carl Nielsen efter Johan Svendsens afgang ville være en oplagt mulighed. Også teatrets direktør, Einar Christiansen, var positivt stemt for Carl Nielsen. De havde tidligere arbejdet sammen, idet Einar Christiansen skrev teksten til operaen Saul og David. Imidlertid ønskede Carl Nielsen kun at tiltræde, hvis de to kapelmesterstillinger blev sidestillet, så han ikke fik en underordnet position i forhold til Frederik Rung.

Det førte til forhandlinger gennem længere tid, og resultatet blev, at kapelmesterstillingerne blev sidestillet, dog med bibeholdelse af titlerne: 1. og 2. Kapelmester.

Fra teatrets side var det dog en aftale med forbehold. I den officielle indstilling fra Det Kongelige Teaters ledelse til Ministeriet for Kultur- og Undervisningsvæsenet i brev, dateret 14 . maj 1908, skriver de:

„... Til ansættelse som 2 . Kapelmester indstilles Komponisten $\mathrm{Hr}$. Carl Nielsen. Da man ikke med Sikker-

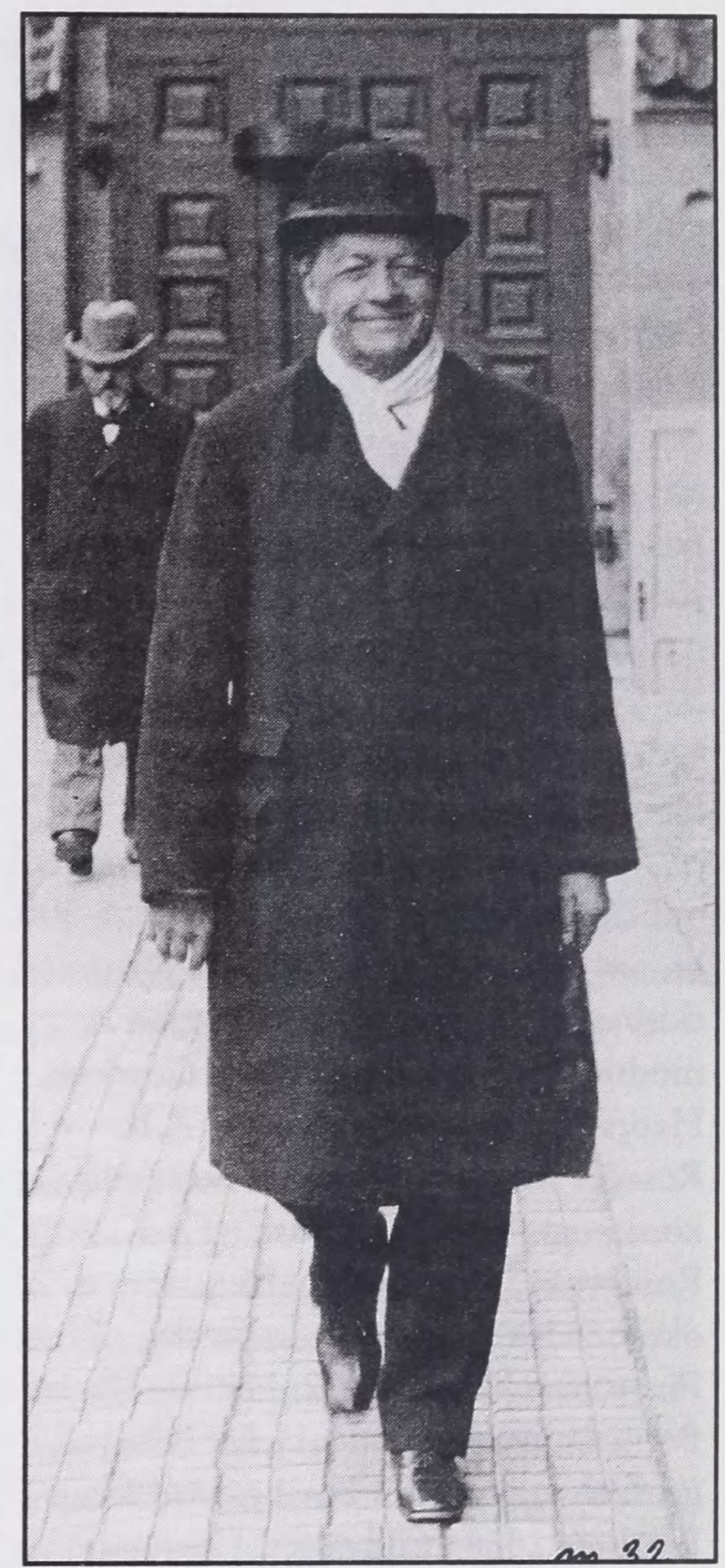

Klaus Berntsen.

hed ved, om Hr. Nielsen kan gøre tilstrækkelig Fyldest i den ham tilbudte Kapelmester-Stilling, anser man det for rigtigst foreløbig ikke at ansætte ham fast, og der foreslaas ham derfor tillagt et Honorar af 4.500 Kr. aarlig af Konto „Engagementer for et Aar eller for kortere Tid“.

I Henhold til Foranførte tillader jeg mig at indstille: 
at 2. Kapelmester Frederik Rung oprykker paa Pladsen som 1. Kapelmester ved det kgl. Teater fra 1. Juli d. A at regne,

at der fra samme Tid henlægges ham en aarlig Lønning af ialt 6.000 Kr. (4.500 Kr. med Ret til Alderdomsforsørgelse og 1.500 Kr. som midlertidigt Tillæg) og

at Komponisten Hr. Carl

Nielsen ansættes som 2. Kapelmester ved det kgl. Teater ligeledes fra 1. Juli d. $A$ at regne mod et aarligt Honorar af $4.500 \mathrm{Kr}$., der afholdes af Konto „Engagementer for et Aar eller for kortere Tid“.

skjold Samsøe)

$$
\text { (Underskrevet C.C. Danne- }
$$

Ministeriet fulgte teatrets indstilling, og i brev, dateret 30. maj 1908, bekræftes ansættelsen af Frederik Rung og Carl Nielsen som henholdsvis 1 . og 2. Kapelmester efter ovenstående model. Imidlertid meddeles det ikke Carl Nielsen, at ansættelsen var midlertidig. Teatrets ledelse skriver til Carl Nielsen i et brev, dateret 5. juni 1908:

„Det meddeles Dem herved til behagelig Underretning, at Ministeriet for Kirke- og undervisningsvæsenet under 30. f.M. har bifaldet, at De ansættes som 2. Kapelmester ved det kongelige Theater fra 1. Juli d. A at regne mod et aarligt Honorar af 4.500. kr. Et Exemplar af Tjenestereglementet vedlægges“.

Heller ikke af ansættelseskontrakten mellem Det Kongelige Teater og Carl Nielsen af 10. maj 1908 fremgår det, at ansættelsen er midlertidig.

En genforhandling af kontrak- ten året efter finder tilsyneladende ikke sted. Der findes ingen kopier desangående i teatrets kopibøger og heller ikke henvisninger til en genforhandling $i$ teatrets journal.

Klaus Berntsen kommenterer afgørelsen således i brev, dateret 14.5.09: „...Dernæst vil jeg udtale min Glæde over og Tilfredshed med vedlagte Kontrakt. Jeg finder ikke, der i Følge dens Indhold er Spor af Grund til Misnøje. Ved Deres Energi og Dygtighed vil De med den Kontrakt som Baggrund for Deres Stilling til Theatret let erobre det tabte tilbage og knytte Dem fast baade til Publikum og Theater, og for Ministeriet er De jo tryg [i] Øjeblikket“. På grund af den manglende genforhandling kan det antages, at dateringen af dette brev er forkert. På brevet står 14.5.09, men der kan være tale om 14.5.08. Omvendt kan det undre, at Klaus Berntsen personligt sender kontrakten til Carl Nielsen, jf. ordlyden: „.. med vedlagte Kontrakt...“, hvis der ikke er tale om en genforhandlet kontrakt fra 1909, der af en eller anden grund ikke er opført i teatrets kopibog eller journal. I alle tilfælde må Klaus Berntsen have haft ganske tætte forbindelser til teatrets ledelse.

Klaus Berntsen var ikke administrativt tilknyttet Det Kongelige Teater, men han må på det tidspunkt have været velorienteret om dets forhold og i nær kontakt med teatrets ledelse, idet han er ordfører for det udvalg i Folketinget, der i april 1908 afgav en betænkning om Lov om forlængelse af Gyldigheden af Lov af 13. marts 1903 om Det Kongelige Teaters Stilling og 


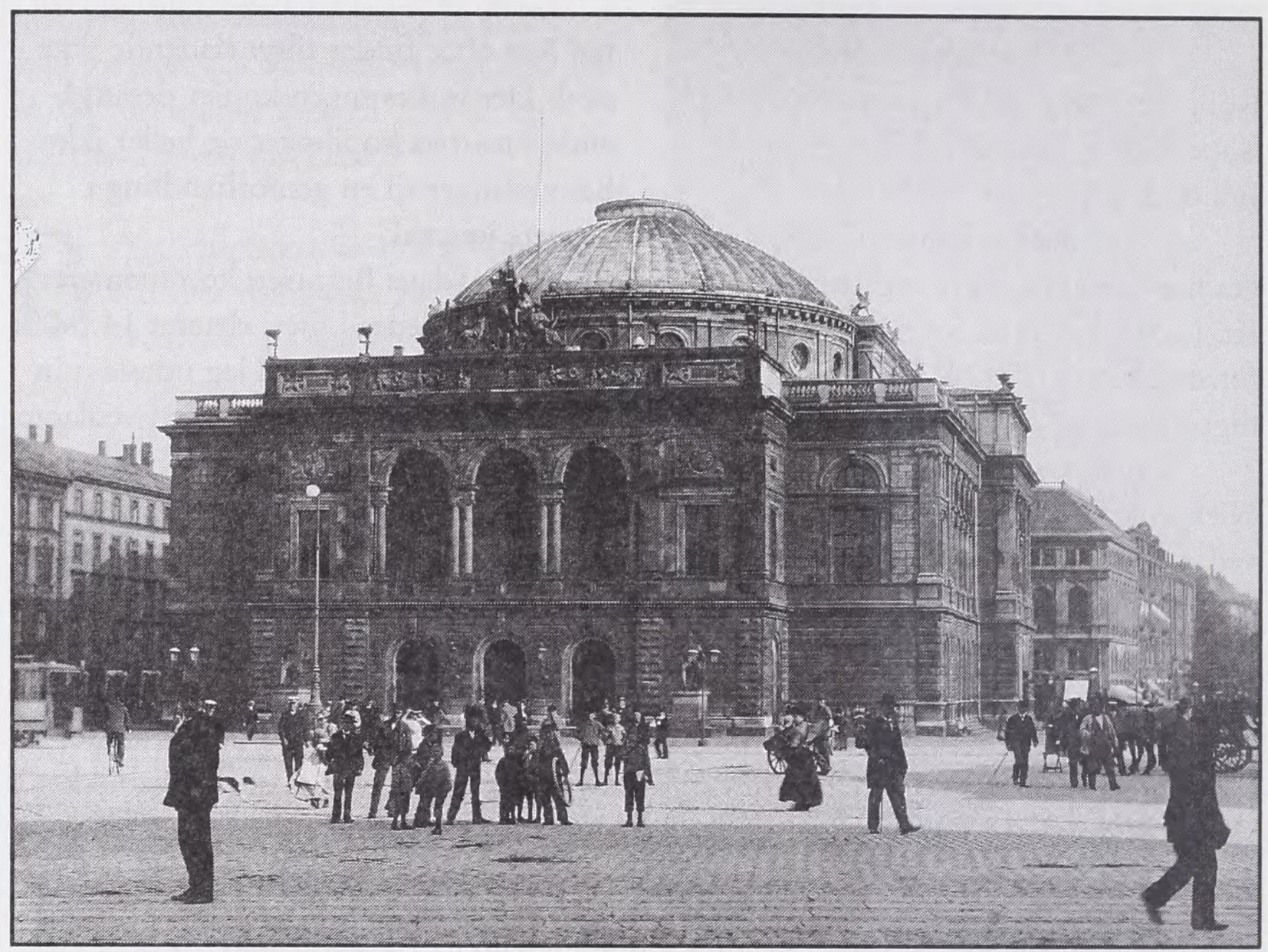

Det kgl. Teater, ca. 1900.

økonomiske Forhold. Det er næppe sandsynligt, at Klaus Berntsens anbefaling er direkte udslagsgivende, men han må have haft mulighed for at gøre sin indflydelse gældende.

Diskussionen om Klaus Berntsens indflydelse på Carl Nielsens ansættelse ved Det Kongelige Teater forløb også i samtiden. I januar 1909 var flere aviser involveret $i$ en polemik, foranlediget af en artikel omhandlende dirigenter, som komponisten og professoren August Enna skrev i medlemsbladet for Københavns Orkesterforening. Han skriver således:

„....Man er herhjemme i denne Tid just Vidne til, hvorledes det kgl. Teaters Direktør har valgt en ganske urutineret Mand til Dirigent, oven i Købet en Mand, som aldrig har lagt særlige Dirigentevner for Dagen, medens Teatret, der ejer en dygtig, paalidelig Dirigent, søger at trænge ham bort til Fordel for den ny udygtige. Klike og Politik burde dog være bandlyst, naar en saa vigtig og betydende Post som Kapelmester i det kgl. Kapel skal besættes.

\section{Den Tryghed og Sikkerhed,} Johan Svendsen bragte over alle Kapellets Præstationer, kan man naturligvis ikke forlange, at den nye, yngre Kapelmester, Carl Nielsen, som nu træder til, skal kunne give det; men man maa kunne fordre af ham, at han ikke paatager sig Opgaver, han ikke kan magte, 
og derved udsætter vor Opera for en Skandale og Demoralisation, som nødvendigvis maa blive Følgen af en saa vaklende og ufærdig Direktion som den, der stadig har fulgt alle de OperaOpførelser, han har ledet.“

August Ennas udtalelse blev bragt i flere aviser: Nationaltidende, Vort Land, Socialdemokraten og Dannebrog. Nationaltidende skriver d. 11.1.09 efter at have bragt citatet:

„Der er i Prof. Ennas Udtalelser et Moment, man særlig standser ved; det er Udtrykket „Klike og Politik“.

At der bestaar - og i mange

Aar har bestaaet - en Klike, der har dannet ligesom en Livvagt om Hr. Carl Nielsen, ja i Grunden har optraadt som Menighed og i ham har dyrket den eneste saliggørende Frelse for vort Musikliv, - det er noget, man længe har vidst. Men at der ogsaa var gaaet P o l i t i k i Carl Nielsen, hans Musik og hans kunstneriske Løbebane, - havde man i Grunden tænkt sig det? Og dog forholder det sig, efter hvad der fortælles os fra indviet Side, saaledes. En Venstre-politiker i en særlig efter det sidste Ministerskifte meget fremskudt Stilling har, besjælet af rent personlig eller lokalpatriotisk Interesse for Carl Nielsen, nok til Fordel for sin Klients anbringelse i Kapelmester-Stolen slaaet et ordentligt Slag i Bordet hos vedkommende Myndighed, der havde Stolen at give bort.

Det kan være, at den gode, gamle Sætning: Den, Gud giver et Embede, giver han ogsaa Forstand, ikke gælder om alle vore Ministre i disse Tider. Men det er højst beklageligt, når Ministeriet giver en Kapelmesterpost til en Mand, der savner KapelmesterForstand."

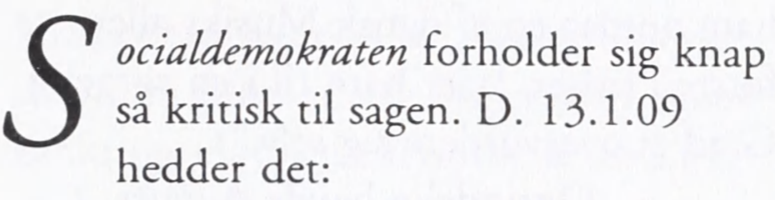

„Den Venstre-Politiker, som „Ratt“ sigter til, er Indenrigsministeren, Hr. Klaus Berntsen. Det forholder sig saaledes, at $\mathrm{Hr}$. Berntsen tog sig af $\mathrm{Hr}$. Carl Nielsen, da denne endnu var et fattigt ungt Menneske, og dette bør vel ikke bebrejdes ham. Da Hr. Nielsen blev Kapelmester, var Hr. Berntsen ikke Minister, og forøvrigt er Hr. Carl Nielsen en saa betydelig Komponist og Dirigent, at han talte sine egne Evner for den fremragende Plads, som han indtager."

Dannebrog lader d. 15.1.09 artiklens forfatter August Enna komme til orde:

„...Jeg kan kun gentage, hvad jeg skrev i min Artikel. Man kan ikke forlange, at en yngre Kapelmester som Carl Nielsen, strax han træder til, skal være en Johan Svendsen. Men han maa ikke paatage sig Opgaver, som han ikke kan magte. Hvis han fortsætter, som han er begyndt, saa udsætter han vor Opera for Skandale og Demoralisation.

Og det er ikke noget, jeg siger for at komme Carl Nielsen til Livs. Jeg synes tværtimod, det er Synd, at han skal havne et Sted, hvor han ikke kan bunde. Maaske er Skylden ikke saa meget hans egen som hans Venners. Han har altid været udsat for en meget farlig, ganske ukritisk, ja hysterisk Tilbedelse og det er jo ikke sundt.

Det har sat Mærker i hans Kompositioner, som med Aarene er 
blevne daarligere - synes jeg - og det har ogsaa i dette Tilfælde, hvor man stillede ham op paa en af dansk Musiks aller første Pladser, faaet ham til i en sørgelig Grad at overvurdere sig selv."

Oprindelig havde August Enna planlagt en fortsættelse af artiklen. Formanden for Københavns Orkesterforening, Wilhelm Fischer, udsendte imidlertid en pressemeddelelse $d$.

12.1.09, hvori han meddeler, at ansvaret for at bringe artiklen i Orkesterforeningens Medlemsblad udelukkende lå hos bladets redaktør, Carl Behrens, og at den planlagte anden del af artiklen ikke ville blive bragt. Bestyrelsen havde ikke set artiklen, inden den forelå i bladet, og et så stærkt angreb på en udøvende dirigent fandt man ikke var foreningens anliggende. Følgen af pressemeddelelsen blev, at Carl Behrends fratrådte som redaktør af bladet. I øvrigt var Carl Nielsen tilsyneladende ikke mere påvirket af sagen, end at han melder sig ind $\mathrm{i}$ Københavns Orkesterforening $\mathrm{i}$ februar 1909.

\section{Militærmusikken}

I sin egenskab af konseilspræsident og Forsvarsminister 1910-1913 havde Klaus Berntsen overtaget Lov om Hærens Ordning af 30. sept. 1909. Ifølge denne lov skulle militærorkestrene reduceres fra ialt 339 mand til 62 mand. I loven var indlagt en overgangsbestemmelse, som fastlagde den endelige effektuering af loven til d. 1. april 1911. Klaus Berntsen fremsætter et nyt lovforslag d. 7. november $1910 \mathrm{i}$ et forsøg på at forhindre den meget drastiske reducering af antallet af musikere ved regimen- terne. I følge det nye lovforslag skulle antallet af musikere nedsættes til 293 mand: 188 „I linjen“ og 105 „faste $\mathrm{Mu}$ sikere af Reserven samt værnepligtige musikere". Lovforslaget blev vedtaget: Lov om Hærens musikere af 1. april 1911.

Af Carl Nielsens dagbogsoptegnelser fra 1911 fremgår, at han d. 10.2.1911 skriver et brev til Klaus Berntsen om militærmusikken. Brevet er bortkommet, men Klaus Berntsens svar kendes:

„Nej, De maa endelig ikke skrive mod Militærmusikken, det vil bedrøve mig, hvis De gør det. Jeg har ikke sat Deres Navn i Forbindelse med den Sag. Vi var jo enige om, G Musiken [Garnisons musikken] kunde lave ordentlig Musik og ikke 10 eller 12 i et Orkester. Forslaget om Assistance af Værnepligtige maa gerne gaa ud af Forslaget. Det er godt at have noget at slaa af paa.

Kan jeg gennemføre Forslaget iøvrigt, som det er, maa jeg være glad, og der kan i Tiden bygges videre derpaa, men faar jeg intet nu, er den Sag skrinlagt for lange Tider.....

Se nu at blive rask, saa kan vi mundtlig tales ved, men min Militærmusik maa De lade mig beholde i Fred, den kan møde Modstand nok endda."

Carl Nielsen efterkom Klaus Berntsens ønske, selv om han tilsyneladende havde haft intentioner om at støtte Klaus Berntsens forslag offentligt. Han havde tidligere udtalt sig om emnet til Fadrelandet, National og Illustreret Tidende d. 8.1.1911, hvor han taler varmt for bevarelse af militærmusikken 
på grund af den opmuntrende virkning både for soldaterne og for befolkningen omkring garnisonerne. Senere er Carl Nielsen medunderskriver på en henvendelse til Regeringen og Rigsdagen, iværksat af O. Gottschalksen i 1914, hvor 174 kulturpersonligheder protesterede over militærmusikkens bemandingsforhold. Man foreslår, at hvert regiment skal have mindst 20 musikere, men forslaget blev nedstemt. I 1916 kommenterer Carl Nielsen igen militærmusikkens vilkår i Charles Kjerulfs pjece: Militærmusikken som den er, som den var og som den burde Være. Carl Nielsens udtalelser heri citeres i endnu en henvendelse, også denne gang iværksat af O. Gottschalksen, hvor det foreslås, at regimenterne skal have mindst 15 musikere. Gottschalksen opfordrer Carl Nielsen til at blive formand for den komite, der står bag forslaget. Han afslår opfordringen på grund af sygdom men skriver dog under blandt 10 underskrivere.

Klaus Berntsen er konseilspræsident og forsvarsminister fra 1910 til 1913 og forsvarsminister igen fra 1920 til 1922. Det er påfaldende, at han ikke $ø$ nsker et samarbejde med Carl Nielsen i en sag, hvor de har samme holdning.
Formodentlig ligger der taktiske motiver bag.

Klaus Berntsen og Carl Nielsen havde meget til fælles: deres baggrund i egnen omkring Højby, bekendtskab med hinandens familier, et nært venskab, karakteregenskaber som humor og lune. At Carl Nielsen har haft gavn af venskabet med Klaus Berntsen, fremgår af de eksempler, som er fremdraget i det foregående. Klaus Berntsen har via sin position som folketingsmand haft mulighed for at påvirke beslutninger omkring Carl Nielsen, hvor det væsentligste eksempel må siges at være Carl Nielsens udnævnelse til 2. Kapelmester ved Det Kongelige Teater. Af avisdebatten omkring udnævnelsen fremgår, at man i samtiden var vidende om dette forhold.

\section{Om Klaus Berntsen tilsva-} rende har kunnet bruge Carl Nielsen til fremme af sine ideer, er der ikke helt så tydelige eksempler på, men meget tyder på, at Carl Nielsens livshistorie ligger på linje med de idealer, Klaus Berntsen som højskolemand og politiker yndede: en mand der fra ikke lærde kredse i provinsen med støtte og opmuntring arbejder sig frem til en vis position i det københavnske kulturliv. 